\title{
Incidence of thrombophilia in patients with recurrent pregnancy loss
}

\author{
Ganesh Bharaswadkar*
}

Department of Obstetrics and Gynecology, ESIC PGIMSR and Model Hospital, Andheri-East, Mumbai, Maharashtra, India

Received: 14 September 2019

Revised: 27 January 2020

Accepted: 01 February 2020

\author{
*Correspondence: \\ Dr. Ganesh Bharaswadkar, \\ E-mail: ganeshbharaswadkar@rediffmail.com
}

Copyright: (c) the author(s), publisher and licensee Medip Academy. This is an open-access article distributed under the terms of the Creative Commons Attribution Non-Commercial License, which permits unrestricted non-commercial use, distribution, and reproduction in any medium, provided the original work is properly cited.

\section{ABSTRACT}

Background: Approximately 1-3\% of women of reproductive age suffer from recurrent pregnancy loss. Objective of this study was to evaluate the association between recurrent pregnancy loss and thrombophilia.

Methods: This is a descriptive study, involving retrospective analysis of patients with recurrent pregnancy losses. Patients with recurrent pregnancy loss in whom associated morbidity factors were excluded underwent screening for both acquired and inherited thrombophilia.

Results: A total of 20 patients were screened for acquired and inherited thrombophilia with recurrent pregnancy loss. Thrombophilia was diagnosed in $70 \%$ cases. Out of which, anticardiolipin antibodies was found positive in $57 \%$ of patients, protein $\mathrm{C} 7 \%$ and protein $\mathrm{S}$ deficiency was observed in $35 \%$ cases.

Conclusions: Thrombophilias are associated with recurrent pregnancy loss. Patients in whom other associated morbid factors are excluded, should be offered screening for thrombophilia. Multidisciplinary management involving hematologist is vital for management.

Keywords: Abortion, Antithrombotic therapy in pregnancy, Antiphospholipid antibody syndrome and pregnancy, Protein C deficiency and pregnancy, Recurrent pregnancy loss, Thrombophilia

\section{INTRODUCTION}

Approximately $1-3 \%$ of women of reproductive age suffer from recurrent pregnancy loss. ${ }^{1}$ In one-third cases, there is no etiology identified, and the remaining have a persistent underlying cause for their pregnancy losses. The common causes of recurrent pregnancy loss are uterine anomalies, endocrine disorders, immunological factors and parental chromosomal abnormalities including those associated with antiphospholipid antibody syndrome and infections. Even after a thorough evaluation, however, the potential cause remains unexplained in about one third of cases..$^{2,3}$

A number of studies have reported an increased risk of RPL in women with inherited thrombophilia. ${ }^{4-6}$ In the European prospective cohort study on thrombophilia
(EPCOT), a significant association between thrombophilia and miscarriage was reported. ${ }^{7}$ The term thrombophilia is generally used to describe a hematological abnormality which increases the tendency to venous thromboembolism in any site or pulmonary embolism.

Thrombophilia can be acquired or hereditary. Hereditary thrombophilia includes a number of conditions, such as antithrombin (AT) III deficiency, protein S (PS) and protein $\mathrm{C}$ (PC) deficiencies, factor $\mathrm{V}$ Leiden, prothrombin 20210A mutation, elevated factor VIII level, and mutation of gene encoding the enzyme methylenetetrahydrofolate reductase (MTHFR).

It is still not certain if heritable thrombophilia causes recurrent miscarriage, and routine testing in women with 
recurrent miscarriage is preferable but not currently advocated. ${ }^{8}$ The principal acquired thrombophilic states include APS and hyperhomocysteinemia. ${ }^{9}$ Thrombophilia has been suggested to be a cause for microembolism in the placenta resulting in abortion or adverse outcome of pregnancy.

The objective of the study was to evaluate the association between thrombophilia and recurrent pregnancy loss which is so far not conclusively evaluated and may help in future to successfully treat cases of recurrent pregnancy loss with this condition.

\section{METHODS}

This is a descriptive case series, incorporating a retrospective analysis of patients with recurrent pregnancy loss in whom other associated morbid factors are excluded. Screening for thrombophilia was carried out in patients with above obstetric complication.

\section{Inclusion criteria}

- Cases with confirmed diagnosis of thrombophilia.

\section{Exclusion criteria}

- Cases with cervical incompetence, uterine anomalies, thyroid disorder, diabetes mellitus, auto-immune disorders and chromosomal anomalies.

A total of 20 patients were screened in the above series, from January 2010 to January 2012, over a period of 25 months. Thrombophilia screening was carried out from a single laboratory providing test facilities for both acquired and inherited thrombophilia.

Screening was carried out six weeks after delivery. Recurrent pregnancy loss is defined as three consecutive first trimester or second trimester pregnancy losses. Women having bad obstetric history viz three first trimester losses, or two fetal losses during second trimester or one fetal loss during third trimester were included in the study.

Mentioned below are Table 1 showing relative and cumulative frequencies of individual thrombophilic condition from given sample population.

Table 1: Estimate of frequency of thrombophilia in given sample population.

\begin{tabular}{|lllll|}
\hline Class & Value & Frequency & Relative & Cumulative \\
\hline 1 & Activated protein C resistance & 0 & 0.0000 & 0 \\
\hline 2 & Anti-thrombin & 0 & 0.0000 & 0 \\
\hline 3 & Anticardiolipin antibodies & 8 & 0.5714 & 8 \\
\hline 4 & Protein C deficiency & 1 & 0.0714 & 9 \\
\hline 5 & Protein S deficiency & 5 & 0.3571 & 14 \\
\hline & Cum. Rel. & & & \\
\hline Class & Frequency & & & \\
\hline 1 & 0.0000 & & & \\
\hline 2 & 0.0000 & & & \\
\hline 3 & 0.5714 & & & \\
\hline 4 & 0.6429 & & & \\
\hline 5 & 1.0000 & & \\
\hline
\end{tabular}

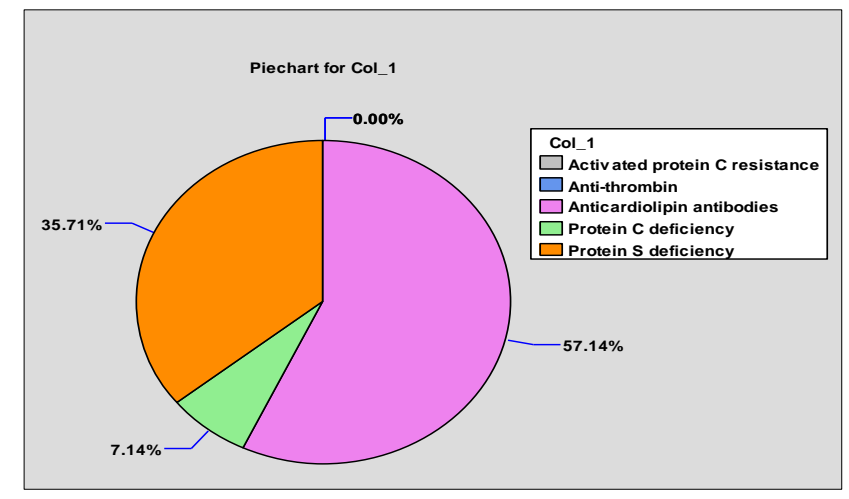

Figure 1: proportion of each Thrombophilic conditions.

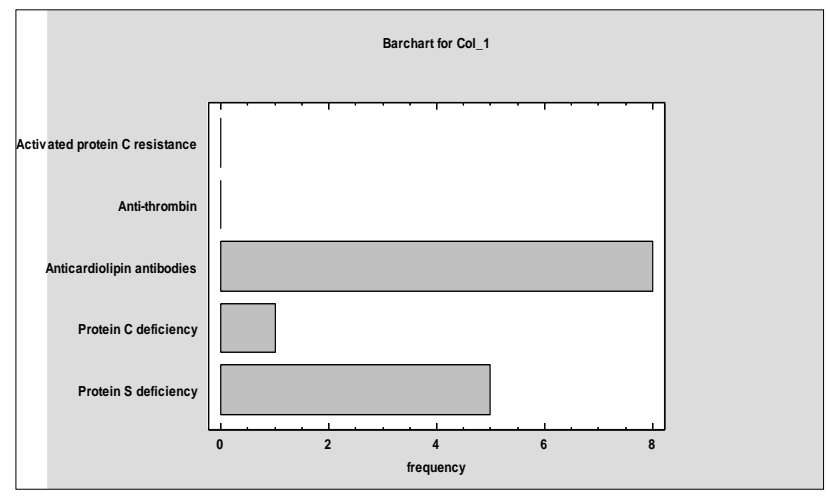

Figure 2: Proportion of each Thrombophilic conditions. 


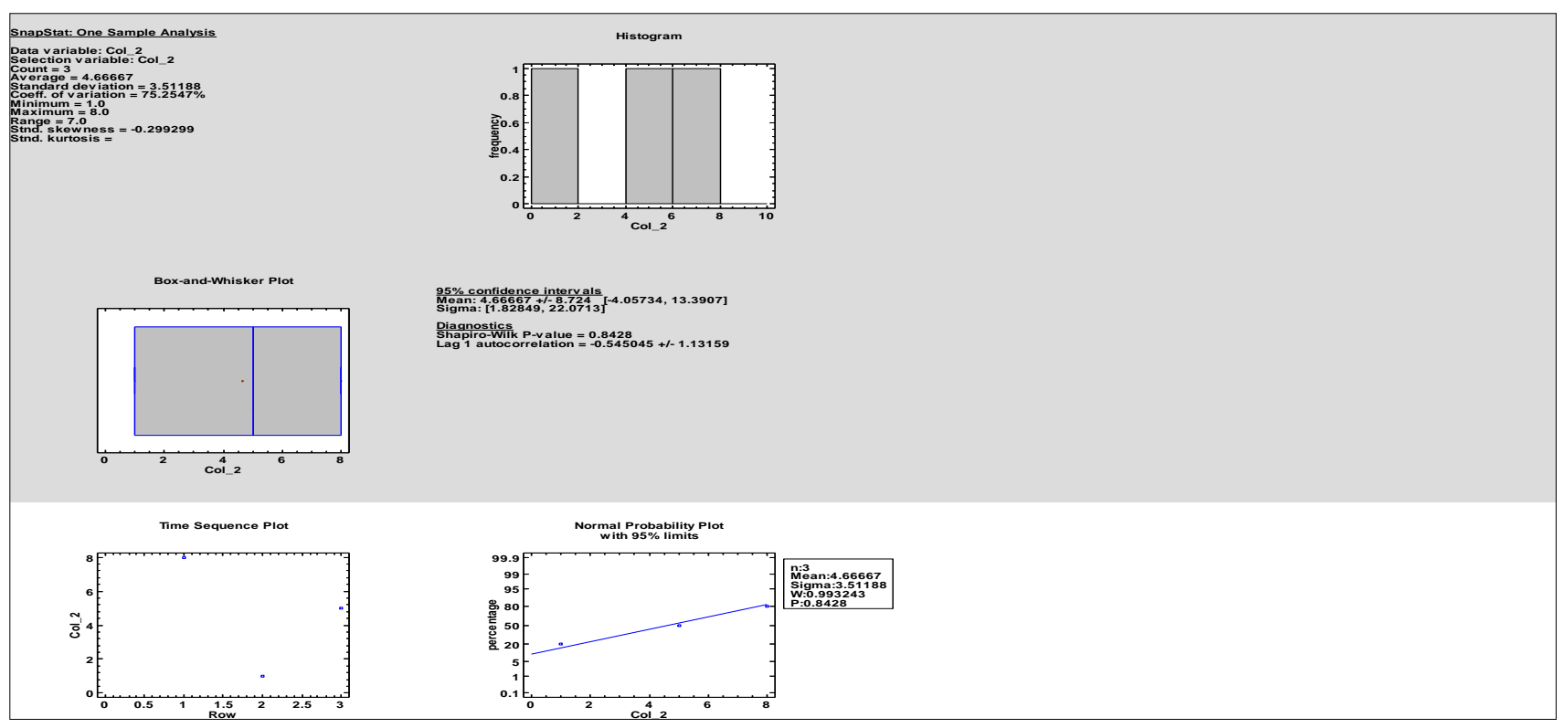

Figure 3: Statistical analysis.

Figure 1 shows percentage distribution of individual thrombophilic condition. Highest percentage is observed for anti-phospholipid antibodies. Figure 2 depicting graphic proportion of thrombophilic conditions.

Figure 3 shows statistical calculations.

\section{RESULTS}

Thrombophilia was detected in 14 patients under evaluation for recurrent pregnancy loss. Table shows the results of screening. Anti-cardiolipin antibodies (57\%), natural anticoagulants protein $\mathrm{C}(7 \%)$ and protein $\mathrm{S}$ (35\%) were found deficient.

Table 2: Estimate of thrombophilia screen positive in patients with recurrent pregnancy loss.

\begin{tabular}{|ll|}
\hline Estimate of thrombophilia & \\
\hline Anticardiolipin antibodies & 08 \\
\hline Protein C deficiency & 01 \\
\hline Protein S deficiency & 05 \\
\hline Anti-thrombin & 00 \\
\hline Activated protein C resistance & 00 \\
\hline
\end{tabular}

Out of 20 patients who were screened, 14 (70\%) patients were found screen positive for thrombophilia.

\section{DISCUSSION}

This was a descriptive study, which was done to see the association between recurrent pregnancy loss and thrombophilia.
The mechanism, leading to recurrent pregnancy loss involves impaired placental development and function. ${ }^{4}$ The association between recurrent pregnancy losses and anticardiolipin antibodies is well established. Out of 20 women with recurrent loss, 08 screened positive for anticardiolipin antibodies, 1 had protein $\mathrm{C}$ deficiency and 5 had protein $\mathrm{S}$ deficiency. Positive Anticardiolipin antibodies are associated with pregnancy loss at all gestational ages.

Women deficient in natural anticoagulants like protein $\mathrm{C}$ and $\mathrm{S}$ and antithrombin III, have been found more prone to utero-placental microthrombosis, leading to recurrent pregnancy loss. ${ }^{4-6}$ Recurrent pregnancy losses have also been attributed to factor $\mathrm{V}$ leiden mutation.

Though the incidence of thrombophilia is low in general population, there is a strong association with recurrent pregnancy loss. ${ }^{7}$ These complications do recur in subsequent pregnancies; hence there is advantage of screening and offering prophylaxis in the subsequent pregnancy for healthy outcomes.

The major limitation of the study is that the screening done during the antenatal or immediate post-natal period within 4 weeks will yield false positive results. Hence the cases need to be evaluated in non-pregnant state and often patient fails to follow up for evaluation after pregnancy loss.

This will help in subsequent management of these patients in pregnancy by adequate antithrombotic therapy which can be initiated from very early days of pregnancy to prevent placental vasculopathy and coagulation 
defects, and thereby improve maternal and perinatal outcomes of these pregnancies to a great extent.

Funding: No funding sources Conflict of interest: None declared

Ethical approval: The study was approved by the Institutional Ethics Committee

\section{REFERENCES}

1. Regan L, Rai R. Epidemiology and the medical causes of miscarriage. Baillieres Best Pract Res Clin Obstet Gynaecol. 2000;14:839-54.

2. Alberman E. The epidemiology of repeated abortion. In: Beard RW, Sharp F, editors. Early pregnancy loss: mechanisms and treatment. New York: Springer; 1988:9-17.

3. Stephenson MD. Frequency of factors associated with habitual abortion in 197 couples. Fertil Steril. 1996;66:24-9.

4. Sanson BJ, Friedrich PW, Simioni P, Zanardi S, Huisman MV, Girolami A, et al. The risk of abortions and stillbirth in antithrombin, protein $\mathrm{C}$, and protein $\mathrm{S}$ deficient women. Thromb Haemost. 1996;75:387-8.
5. Brenner B, Sarig G, Weiner Z, Younis J, Blumenfeld Z, Lanir N, et al. Thrombophilic polymorphisms are common in women with fetal loss without apparent cause. Thromb Haemost. 1999;82:6-9.

6. Dossenbach-Glaninger A, Trotsenburg M, Dossenbach MR, Oberkanins C, Huber J, Hopmeier P. Elevated coagulation factor VIII and the risk for recurrent early pregnancy loss. Thromb Haemost. 2004;91(4):694-9.

7. Preston FE, Rosendaal FR, Walker ID, Briet E, Berntorp E, Conard JA, et al. Increased fetal loss in women with heritable thrombophilia. Lancet. 1996;348:913-6.

8. Walker ID, Greaves M, Preston FE. Investigation and management of heritable thrombophilia. $\mathrm{Br} \mathrm{J}$ Haematol. 2001;114:512-28.

9. Hague WM. Homocystein and pregnancy. Best Pract Res Clin Obstet Gynaecol. 2003;17:459-69.

Cite this article as: Bharaswadkar G. Incidence of thrombophilia in patients with recurrent pregnancy loss. Int J Reprod Contracept Obstet Gynecol 2020;9:1007-10. 